\title{
Consumer Perceptions of Syariah Bank and Location (An Overview of Merchants Interest in Choosing Microfinance Financing for Syariah Banking in Bireuen District)
}

\author{
Hamdani ${ }^{1}$, Wahyuddin Albra ${ }^{2}$, Nazir $^{2}$, M Heikal $^{2}$, Mulia Saputra ${ }^{3}$, Sri Gustini ${ }^{4}$, \\ Damanhur Abbas ${ }^{5}$ and Henry Aspan ${ }^{6}$ \\ \{hamdani@pnl.ac.id\} \\ ${ }^{1}$ Department of Business Administration Studies Banking Finance, Politeknik Negeri Lhokseumawe, \\ Aceh, Indonesia \\ ${ }^{2}$ Department of Management, Universitas Malikussaleh, Aceh, Indonesia \\ ${ }^{3}$ Department of Accounting, Universitas Syiah Kuala, Aceh, Indonesia \\ ${ }^{4}$ Departement of Economic Management, STIE Rahmaniyah Sekayu, Sekayu, Indonesia \\ ${ }^{5}$ Department of Islamic Economics, Universitas Malikussaleh, Aceh, Indonesia \\ ${ }^{6}$ Department of Management, Universitas Pembangunan Panca Budi, Medan, Indonesia
}

\begin{abstract}
This study aims to determine consumer perceptions about syariah bank and location reviewed from the interest of merchants choosing micro business financing in sharia banking in Bireuen regency. Data collection method used in this research is survey using questionnaire. The sampling technique used cluster and sampling method. The population of this research is all traders of micro business located in 17 sub districts in Bireuen Regency which amounted to 2101 traders and samples of 100 traders that is an average of 5.9 per kecamatan. The result of research shows that consumer perception about syariah bank and location shows positive and significant influence, so that traders are interested in choosing micro business financing in syariah banking in Bireuen District.
\end{abstract}

Keywords: Perception, Shariah Bank, Location, Micro Business, Trader, Interests.

\section{Introduction}

The rotation of the economy wheel in a country is influenced by the participation and the role of various business sectors. Therefore, to strengthen the economic foundations the government needs to promote the business sector in various fields, so that prosperity will be realized.

The Central Bureau of Statistics launched in 2010 the number of workers reached 116.5 million people, in 2011 that is 119.4 million people, in 2012 amounted to 120.3 million people, in 2013 that is 120.2 million people, 2014 amounted to 121.9 million people, 122.4 people, and in 2016 as many as 127.8 million people [1].

From these data can be seen employment absorption shows an increase in every year. The largest absorption of energy is in the MSME sector, on average per year UMKM can open employment opportunities for $8,396,823.5$ people, or $64.23 \%$ of the total number of business actors in Indonesia. 
This fact indicates that MSMEs can create jobs, so it can help the economy in terms of reducing the number of poverty, distribution of income distribution and economic development in an area.

In general, this sector of MSMEs business is in the trade sector, in the economic activity of traders have various considerations. The merchant's consideration is related to the determination of the consumption choices and the determination of the costs used to meet the factors of production. Financing for traders is necessary in order to support the smoothness in the provision of stocks of merchandise, because one of the supporting factors required by traders in building a business that is fund or known as financing.

In Indonesia, small-scale businesses have the support of the government. One indication of government support is the presence of ministries dealing with microeconomic growth, where the base is a small community.

In addition to the government, also needed support from various parties, especially financial institutions, such as banking sector, and non-bank institutions. If all parties are committed to assist UMKM, then prospective traders need not be confused to become micro entrepreneurs because of lack of capital.

So far, the limitations of capital severely limit the movement of small traders in running and increasing their business. but with a variety of access to finance institutions, especially the current sharia financing with all the weaknesses and advantages that exist into consideration for traders in determining the choice.

Capital for business can be obtained from two sources namely own capital and from outside among other financial institutions, namely Islamic financial institutions and non-sharia financial institutions. Sharia financial institutions are one of the instruments used to regulate the rules of Islamic economics.

The provision of business capital loan from sharia financial institution is of course temporary, as a stimulus to conduct production activities, so it is expected to increase the income of small businesses. With the increase in income then the welfare and justice of society is expected to be realized.

Sharia financial institutions include Syariah Bank, Syariah People's Financing Bank, Sharia Cooperative, Baitul Mal wat Tamwil and so on. As part of the economic system, the institution is part of the social whole. Therefore, its existence must be viewed in the context of the whole society as well as the values prevailing in society.

Sharia financial institutions have improved since the issuance of ( Law No. 20 of Indonesia, 2008) on sharia banking. The law contains the laws relating to Bank Indonesia as the Central Bank and the laws that form the legal basis for all kinds of banking activities.

Sharia financial institutions as part of the sharia economic system in conducting business and business can not be separated from sharia sieve. Sharia financial institutions also will not finance the efforts in which contained things that are forbidden and with the existence of Islamic financial institutions are expected to overcome or reduce the practice of illegal banks (loan shark) Amid the community, especially traders.

Sharia banking is a banking system that operates based on sharia principles. With the main principles of partnership and togetherness in the system of sharia both the bank and customers get keutungan, because the activities undertaken do not use the system of interest but with the system of profit sharing. Consumer perceptions of all information held such as various products / services are very useful for banks that operate by using sharia system, understand the consumer is very important because what is purchased, where to buy, when to buy and how much is purchased will depend on the consumer knowledge -that matter. Consumer 
perceptions about sharia banking will have an impact on consumer behavior to choose sharia banking.

By seeing the increasingly tight competition in the banking world, the syarah banks must have the right strategy to win the competition, Islamic banks must constantly make various innovations, including designing various products, both fund raising and financing as attractive as possible, in addition to various factors must be considered among other information about the products / services of Islamic banks so that the consumer knowledge of Islamic banks and on the strategic location, customer convenience, and the breadth of the network and so forth. Acehnese in particular in Bireuen district are dominantly Muslim but still limited knowledge of sharia banking by taking loans to loaners who ask for interest in each loan given according to the nominal amount given.

\section{Literature Review}

\subsection{Understanding Islamic Banking}

Bank is a financial intermediary financial intermediary. That is, the bank institution is an institution that in its activities related to the issue of money.

Bank Syariah according to (Indonesia Law Number 21 of, 2008), is a bank that conducts its business activities based on sharia principles and according to its type consists of Sharia Commercial Bank and Sharia Rural Bank. Islamic banks in general are financial institutions whose main business is providing financing and other services in the traffic payments as well as money circulation which operate in accordance with the principles of sharia.

So it can be concluded Islamic banks are financial institutions whose main business provides financing and other services in the traffic payments and circulation of money that operate in accordance with Islamic Shari'ah principles that operate with the principles of Islamic sharia.

\subsection{The role of Sharia Bank}

Concerning the functions and roles ofsharia banks, according to (Muhammad Antonio Syafii, 2001:25) are as stated in the opening accounting standards issued by Accounting and Auditing Organization for Islamic Financial Institution (AAOIFI), as follows:

1. Investment manager, sharia bank can manage customer fund investment.

2. Inverstor, sharia bank can invest its own funds and customer funds entrusted to him.

3. Providers of financial services and payment traffic, Islamic banks can perform banking services activities as usual.

4. Implementing social activities, as a feature embedded in Islamic financial entities, Islamic banks are also obliged to have the obligation to issue and manage (collect, administer, distribute) zakat and other social funds.

Viewed from several aspects in the role above shows that the role of Islamic banks is very useful for consumers who want to choose a sharia bank to conduct banking transactions. 


\subsection{Definition of Financing}

According to ( Law No.10, 1998) No. 7 of 1992, financing is the provision of money or equivalent claims based on borrowing or borrowing purposes between banks and other parties requiring the borrower to repay the debt after a certain period of time plus a certain amount of interest, or the sharing of the results between the investor and the manager.

Meanwhile, according to (Kasmir, 2008:102) Financing (Financing) in conventional banking known as credit terms.

The definition of credit in accordance with Law Number 10 Year 1998 [6] is "Provision of money or claims that can be equalized, based on a loan agreement or agreement between the bank and other parties that require the borrower to repay the money after a certain period of time." If someone uses credit services will be charged.

So it can be concluded that financing is the provision of money based on an agreement between banks with other parties, with the agreement the borrower returns his loan in accordance with the agreement to increase the profit sharing according to the contract agreement.

\subsection{The Role of Micro Enterprises}

The role of micro enterprises according to Sincere, (2009: 45) is a micro business is a business that has an important role in economic development, this is due to the relatively higher labor intensity and smaller performance. So that micro businesses are more flexible in dealing with and adapting to market changes. This causes the micro business not to be severely affected by external pressure, as it can reduce imports and have a high local content. Therefore, the development of micro business can contribute to economic diversification and structural change as a precondition of long-term stable and sustainable economic growth. In addition, the rate of job creation is higher in micro enterprises than in large corporations.

\subsection{Understanding Interest}

According to (Sofjan Assauri, 2011:141) interest is a sense of love or pleasure and a sense of interest in an object or activity without any one telling and usually there is a tendency to search for objects that are liked. Interest is better known as the use or purchase decision of a particular service / product. Purchase decision is a decision-making process of a purchase that includes determining what will be purchased or not making a purchase and the decision is derived from the previous activities of the needs and funds owned.

\subsection{Understanding perception}

Perception according to (Jalaluddin Rakhmat, 2008:51) is the experience of objects, events or relationships obtained by concluding information and interpret the message.

Meanwhile, according perception is a process of sensory clues (sensori) and relevant past experiences organized to give us a structured and meaningful picture in a particular situation. Similarly, Atkitson and Hilgard argue that perception is the process by which we interpret and organize stimulus patterns in the environment. Gibson and Donely explain that perception is the process of giving meaning to the environment by someone else's other characteristics. 


\section{Result and Discussion}

\subsection{Validity Test Results}

Test validity is a reliable data to measure the validity of whether or not the item question or measure the truth in accordance with reality. the authors analyzed the results of processed SPSS version 18.

Level validity is done with terms above 0.05 and by comparing the value of $\mathrm{r}$ arithmetic with $r$ table value, $r$ value calculated from SPSS output in Correlated Item-Total Correlation column. While the r-table value can be obtained through df (degree of freedom) $=\mathrm{n}-\mathrm{k}$ so 100 $12=88$, then r-table $=0.1745$.

From 12 items the question can be concluded that the question stated is all valid, because all correlation values are above 0.05 and the value of $r$-count $>r$-table. So in this study all items in the instrument meet the validity requirements and can measure precisely and accurately.

\subsection{Test Reliability}

Test Reliability shows the results of variable reliability measurement. Reliability test is done by using Cronbach Alpha technique, where an instrument can be said reliable reliably if have reliability coefficient or alpha has value $>0.70$ then the value of reability is high.

Table 1 : Test Reability

Reliability Statistics

\begin{tabular}{|r|r|r|}
\hline $\begin{array}{c}\text { Cronbach's } \\
\text { Alpha }\end{array}$ & $\begin{array}{c}\text { Cronbach's } \\
\text { Alpha Based on } \\
\text { Standardized } \\
\text { Items }\end{array}$ & N of Items \\
\hline 0.773 & 0.789 & 12 \\
\hline
\end{tabular}

The output of SPSS shows the result of Reliabiliy Statistic table that is 0.773 It has been seen before in reliability test material that is if alpha is between $0,70-0,90$ then high reliability. Viewed from Cronbach's Alpha is 0.773 between $0.70-0.90$ then for this test reliability is said to be high.

\subsection{Classic Assumption Test Results 3.3.1 Normality Test Results}

Normality test aims to test whether in the regression model, the dependent variable and the second independent have a normal distribution or not. A good regression model is one that has a normal or near-normal distribution of data. Normal data distribution will form a straight line diagonal and if the data is normally distributed, then the data distribution shown will follow the diagonal line groove. 
Normality testing performed using Normal P-Plot Regression Standardized Residual, Histogram and Kolmogorov-Smirnov. The processed results SPSS version 18 on the test of normality is as follows:

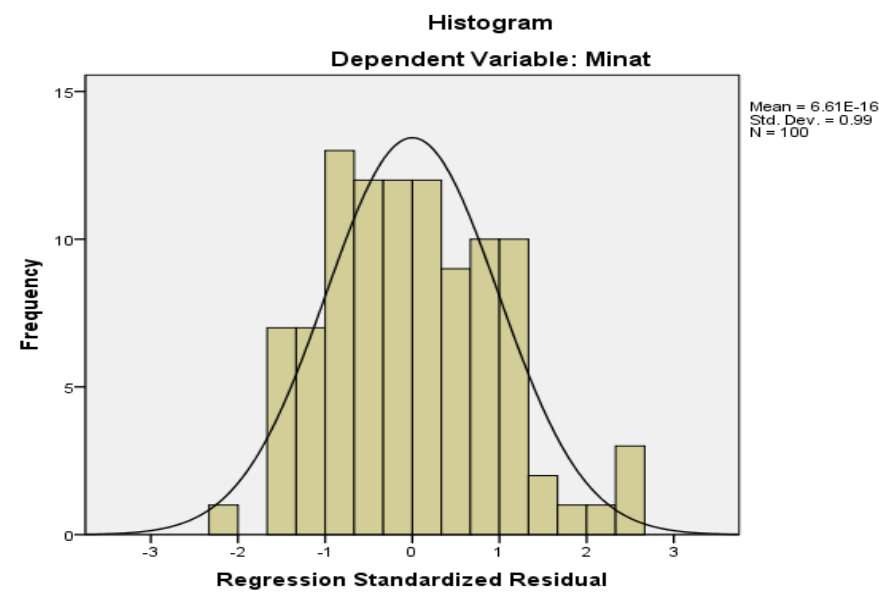

Figure 1: Histogram Chart

Based on Figure 1 above, shows a bell-shaped histogram of zero, the curve does not deviate to the left or deviates to the right (the left and right sides are the same width), it can be said to be normal. Therefore, a normal P-Plot graph is used which illustrates the presence of dots around the diagonal line shown in Figure 2 as follows:

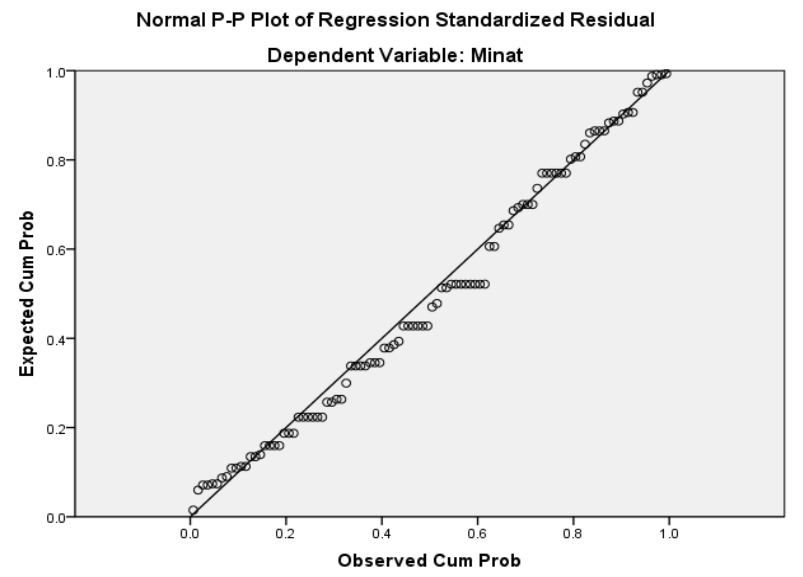

Figure 2: Data Normality

Based on the graph above, the residual data shows the normal curve seen at the points spreading around the normal line (diagonal line), as well as its spread following the direction of the diagonal line. Then the regression model is appropriate for predicting customer satisfaction based on the input of the independent variable or regression model fulfilling the normality assumption.

Another way to do in the classical assumption to know whether the data is normally distributed or not is by the One-Sample Test Kolmogorov-Smirnov test. The result of this 
normality is done from significant value> 0,05 means show regression model has fulfilled normality assumption.

\subsubsection{Multicollinearity Test}

Multikolineritas is a test whether in the regression model found a correlation between independent variables. A good regression model should not be correlated between independent variables. To detect the presence or absence of multicollinality in the regression model can be seen from the tolerance and variance inflation factor (VIF). If the tolerance value $\leq$ of 0 , or equal to the VIF value $\geq$ of 10 , then indicates the presence of multicollinearity and vice versa if the tolerance value $\geq 0.1$ or equal to the VIF value $\leq$ of 10 then the regression model is free of multicolinearity.

VIF (Variance Inflation Factor) and Tolerance. The guideline of a multicolinearity-free regression model is when it has a VIF value below 10 and has a tolerance rating of not less than 0.1. It can be seen that the VIF value on Perception is 1.116 and Location 1.116 is <10, it proves that the regression model model is free from multicollinearity. Similarly Tolerance> 0,1 is Perception which is 0,896 and Location is 0,896 . Thus it can be concluded that the regression model does not occur multicolinearity, so the regression is legitimate to use.

\subsubsection{Heteroscedasticity Test}

Testing whether in a regression model, there is a variance inequality of the residual from one observation to another. If the variance of the residual from one observation to another observes remains, then it is called Homoscedasticity. And if the variance is different, it is called Heteroscedasticity. To detect the presence or absence of heterokedastisitas in the regression model can be seen from the pattern formed at the point contained in the sccaterplot.

The basis for decision making is as follows:

1. If there are certain patterns, such as points (points) that exist in the form of a certain pattern that regular (wavy, widened, then narrowed). Heterocedasticity has occurred.

2. If there is no clear pattern with dots spread above and below zero on the $\mathrm{Y}$ axis, no heteroscedasticity

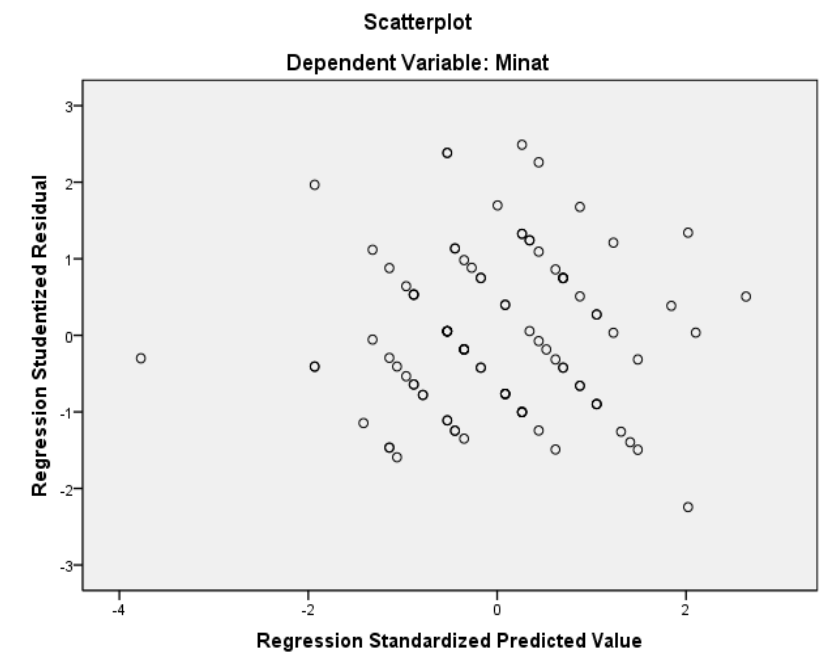

Figure 3: Heteroscedasticity Test Results 
From the Scatterplots graph it appears that the dots of the data spread randomly and spread out either above or below the zeros on the $\mathrm{Y}$ axis and form a certain pattern. It can be concluded that there is no heteroscedasticity in the regression model or the data is homoscedasticity, so the regression model is feasible to be used to analyze consumer perception about syariah bank and location to the interest of the merchant choosing the micro business financing on the syariah banking.

\section{Conclusion}

Based on the results of research conducted it can be taken the following conclusions:

1. Perceptions (X1) and Locations (X2) simultaneously affect the Interest of Traders Selecting Micro Business Financing on Sharia Banking in Bireuen (Y).

2. Perception $(\mathrm{X})$ is partially positive and significant influence on the Interest of Merchants Selecting Micro Business Financing on Sharia Banking in Bireuen Regency.

3. Location (X2) partially has a positive and significant effect on the Interest of Merchant Selects Micro Business Financing on Sharia Banking in Bireuen Regency.

\section{References}

[1] Badan Pusat Statistik, "Berita Resmi Statistik: Pertumbuhan Ekonomi Triwulan I-2017," No.45/05/Th.XX,05 Mei 2017, no. 45, pp. 1-10, 2017.

[2] P. R. Indonesia, "UU Nomor 21 Tahun 2008 Tentang Perbankan Syariah," Undang Undang Republik Indones., vol. 1998, pp. 1-64, 2008.

[3] Muhammad Antonio Syafii, Bank Syariah: Dari Teori ke Praktik. Jakarta: Gema Insani Press, 2001.

[4] U.-U. No.10, “Tentang Perubahan Atas Undang - Undang No.7 Tahun 1992 Tentang Perbankan," Republik Indones., 1998.

[5] Kasmir, Bank dan Lembaga Keuangan Lainnya. Jakarta: PT. Rajagrafindo Persada, 2008.

[6] Bank Indonesia, "Undang-Undang Nomor 10 Tahun 1998 Tentang Perbankan," Undang. NOMOR 10 TAHUN 1998 tentang Perbank., no. Direktur Direktorat Hukum Bank Indonesia, p. $65,1998$.

[7] Sofjan Assauri, Strategic Managemen, Sustainable Competitive Advantages. Jakarta: Lembaga Management Fakultas Ekonomi Universias Indonesia, 2011.

[8] Jalaluddin Rakhmat, Psikologi Komunikasi. Bandung: PT. Remaja Rosdakarya, 2008. 